\title{
The Effect of Internal Revenue Generation on Infrastructural Development. A study of Lagos State Internal Revenue Service
}

\author{
Adesoji Adetunji Adenugba (MR) \\ College of Business and Social Sciences \\ Crawford University \\ Faith - City, Igbesa, Ogun State \\ adesojiadenugba@gmail.com \\ Chike Faith Ogechi \\ Crawford University \\ Faith - City , Igbesa, Ogun State \\ chikeogechi@gmail.com
}

\section{Doi:10.5901/jesr.2013.v3n2p419}

\begin{abstract}
Revenue generation is the nucleus and the path to modern development. Thus, this study assessed the effect of internal revenue generation on infrastructural development. The research methodology entailed the use of survey research design and purposive sampling method to select respondents from Lagos State Inland Revenue Office.. Questionnaires and statistical data were instruments used for the study. Descriptive and inferential statistics were the statistical tool used for the analysis. The descriptive statistics involves the use of simple percentages while the inferential statistics involved the use of Spearman's Rank, which is to show the direction of relationship between variables in the study and to show the scale for the data that is interval. Two hypotheses were formulated and the Spearman's rank correlation analysis was used to test the relationship between internally generated revenue and infrastructural development. The result showed that there is a positive relationship between internally generated revenue and infrastructural development. The study also revealed the various methods of generating internal revenue, which are the enforcement of tax personnel, contribution, and creating awareness to the public. The findings of the study however show that revenue administration agencies need to be reviewed to generate more revenue in the country.
\end{abstract}

Keywords: Infrastructure, Revenue, development, administration, Lagos state

\section{Introduction}

The increasing cost of running government coupled with dwindling revenue has led various State governments in Nigeria with formulating strategies to improve the revenue base. More so, the near collapse of the National Economy has created serious financial stress for all tiers of government. Despite the numerous sources of revenue available to the various tiers of government as specified in the Nigeria 1999 constitution, since the 1970s till now, over $80 \%$ of the annual revenue of the three tiers of government come from petroleum. However, the serious decline in the price of oil in recent years has led to a decrease in the funds available for distribution to the states. The need for state and local government to generate adequate revenue from internal sources has therefore become a matter of extreme urgency and importance. This need underscores the eagerness on the part of state and local governments and even the federal government to look for new sources of revenue or to become aggressive and innovative in the mode of collecting revenue from existing sources.

Development is a sine qua non for modern civilization. In order to carryout development at all nooks and crannies of the society, it is the responsibility of the Lagos State Government to provide direct development to people to a certain level. Development is associated with funds and much revenue is needed to plan, execute and maintain infrastructures at the state level. The needed revenue generated for such developmental projects, 
like construction of accessible roads, building of public schools, health care centres, construction of bridges are generated from taxes, royalties, haulages ,fines, and grants from the states, national and international governments. These funds could either be obtained internally or externally. Thus, the Lagos State Government cannot embark, execute and possibly carryout the maintenance of these projects without adequate revenue generation.

The Lagos state government announced its decision to spend N390b ( $\$ 3$ billion) on infrastructural development in the state over the next couple of years. Speaking during the town hall meeting of the Lagos State Internal Revenue Service (LIRS) for market associations, general merchants, skilled technicians among others, the Governor of Lagos State, Mr Babatunde Raji Fashola disclosed that huge funds are required to put in place the necessary infrastructure that will make life easier in the state.

He said, "The project on the agenda of the state government requires huge funding. Over the next two decades, Lagos State needs to spend at least N390 billion ( $\$ 3$ billion) annually to expand and improve its water supply network. N2.6 trillion ( $\$ 20$ billion) to provide qualitative and efficient network of roads and drainage; N1.3 trillion ( $\$ 10$ billion) for power supply; N650 billion ( $\$ 5$ billion) for information and computer technology; and N1.2 trillion ( $\$ 9.3$ billion) for inter-modal transportation system."

To this end, he called on the artisan and other professionals in the state to ensure they pay their tax so that the government can meet up with plans to develop and improving on social amenities in the state.

He disclosed that the state government has put in place measures that will check tax evasion and ensure that individuals and corporate organizations pay the right tax. He noted that the new revenue administration law of the state provides for tax clearance check before any individual or corporate body is allowed to do business with, obtain any license or enjoy other benefits from the state government.

Revenue generation in Nigeria's local government is principally derived from TAX. Therefore, taxation is an internal source of government revenue within the domestic economy. Its collection and service to the government depends largely on the government itself. Taxation has been described in many ways and for the purpose of this study it will be seen as compulsory levy imposed on a subject or upon his property by the government having authority over his property through its agencies with the aim of providing, maintaining and improving social facilities in the communities at large and for which the tax payer has no quid pro que. This study will examine the effects of revenue generation on infrastructural development in Lagos State by providing anwers to the following research questions:

i. What are the impacts of poor revenue generation on the development of Lagos State?

ii. Has poor infrastructures contributed to the loss of lives?

iii. To what extent is the training of tax personnel the only effective and lasting solution to the problem of revenue generation?

iv. To what extent has the various policy tools used in generating revenue being effective?

\section{Statement of hypotheses}

To determine whether internal revenue is being generated effectively in Nigeria, the following hypothesis would be tested:

$\mathrm{H}_{0}$ : Effective internal revenue generation leads to the development of infrastructure.

$\mathrm{H}_{1}$ : Effective internal revenue generation does not lead to the development of infrastructure.

$\mathrm{H}_{0}$ : There is internal control measures put in place to ensure effective utilization of revenue generated.

$\mathrm{H}_{1}$ : There is no internal control measures put in place to ensure effective utilization of revenue generated.

$\mathrm{H}_{0}$ : There are laid down procedures for revenue collection.

$\mathrm{H}_{1}$ : There are no laid down procedures for revenue collection.

\section{Brief literature review}

\subsection{Revenue}

The term revenue has been defined by various authors in different ways. Adam (2006) defined revenue as the fund required by the government to finance its activities. These funds are generated from different sources such 
as taxes, borrowing, fine, fees etc. It is also defined as the total amount of income that accrues to an organization (public or private) within a specified period of time (Hamid, 2008). States revenue comprises of receipt from taxation as well as those which are not the proceeds of taxation, but of either the realization from the sale of government properties or other interests and returns from loans and investment earning. Bhatia (2001) contends that revenue receipt include "routine" and "earned" income. For these reasons, according to him, revenue do not include borrowing and recovery of loans from other parties, but it includes tax receipts, donations, grants, fees and fines and so on.

Similarly, Pearce (1986) defined government revenue as all the money received other than from issue of and debt, liquidation of investments. Government revenue includes tax collections, charges and miscellaneous revenues, utility and insurance trust revenue for all funds and agencies of a government. Public revenue according to Stephen and Osagie (1985) is concerned with various ways in which the government raises revenue. From the above definitions, it can be said that revenue is the total amount of income accruing to a state from various sources within a specified period of time. State government, like the other two tiers of government, has sources and uses of revenue. Osisami (1994) states that there are basically two types of revenue that accrues to state governments. These are internally generally generated revenue and revenue allocated from the Federation Account.

Internally generated revenue are those revenues that are derived within the state from various sources such as taxes (pay as you earn, direct assessment, capital gain taxes, etc), and motor vehicle license, among others. While the statutory allocation from Federation Account, Value Added Tax constitute the external source. Most states of the federation get the bulk of their revenue in form of statutory allocation from the federation account to finance their expenditure programmes. (Mukhtar, 1996; Isyaku, 1997; Abdulkadir, 1998; Ibrahim, 2002; Ishaq, 2002 and Hamid, 2008). State governments as the second tier of government in Nigeria derive its revenue from various sources. However, it should be noted that sources of revenue are by no means uniform among the states. States derive their revenue depending on the resources available to them; (Anyafo, 1996; Daniel, 1999; and Adam, 2006). The share of federation account to states constitutes 57.97\% in 2002 of the total revenue plus grant and this rose to $65.82 \%$ in 2006; while the internally generated revenue declined from $13.38 \%$ in 2002 to $8.11 \%$ in 2006 (CBN,2006). The average percentages of internally generated revenue in relation to the federal allocation were between 5-9 percent for most non-oil producing states in the recent past. Kano was able to slightly exceed $10 \%$ in 2004 to date due to aggressive revenue generation efforts, with Lagos state as the only exception.

Recurrent expenditure according to Jimoh (2007) is the type of expenditure that happens repeatedly on daily, weekly or even monthly basis. The amount involved is charged to some operating account (e.g. profit and loss account or income and expenditure account).This includes for example payment of pensions and salaries, administrative overhead, maintenance of official vehicles, payment of electricity and telephone bills, water rate and insurance premium, etc.

\subsection{Strategies of revenue generation}

Hofer and Schedal (1978), described strategy as a game plan through which aims and objectives of an organization is achieved. They also defined strategy of revenue generation as the fundamental pattern of present and planned resource department, and environmental interaction that indicate how the organization will achieve its aims and objectives.

However, for effective revenue generation, Hofer and Schedal (1978), suggested the following strategies:

I. Introduction of additional sources of revenue.

II. Providing an incentive for extra efforts of the revenue generation staffs.

III. Periodic raiding by officer of the revenue generation.

IV. Efficient and effective collection of existing taxes.

V. Public enlightment and campaign that will educate the tax payer on the importance of prompt payment. 


\subsection{Revenue administrations}

While tax policy and tax laws create the potentials for raising tax revenues, the actual amount of taxes flowing into the government Treasury, to a large extent, depends on the efficiency and effectiveness of the revenue administration agencies. Weaknesses in revenue administration lead to inadequate tax collections. Financing of the resulting budget deficit through borrowing can cause unsustainable increases in the State public debt. In the alternative, revenue shortfalls shrink the budgetary resource envelope, thus, affecting the government's ability to implement its policies and programmes and provide public services. Unexpected dips in revenue collections also cause budget cuts that result in major inefficiencies in the public expenditure management. Successive Administration of Lagos State in recognition of this developed improved Revenue Administration structure targeted at increasing internal revenue accruable to the government. The main administrative measures taken in the past ten years to improve revenue include:

- Accelerated Revenue Generation Programme (ARGP) - 1994

- CITI Bank Direct Monitoring and Reporting of Internal Revenue System - 1999

- Electronic Banking System of Revenue Collection and Monitoring (EBS-RCM) - 2000

- Granting Full Autonomy to Lagos Board of Internal Revenue - 2006.

\subsection{Challenges of the current revenue administration processes of Lagos State}

Lagos State operates a unique revenue administration structure that has increased the internally generated revenue of the State by almost $400 \%$ in the past six years. However, there are some challenges of the emerging scenario:

- The State prior the creation of the autonomous Board of Internal Revenue had an inefficient, ineffective, illequipped and ill-motivated Board of Internal Revenue that contracted out some of its functions to Revenue Consultants. Alpha-Beta Consulting Limited had the sole mandate of controlling and monitoring the Lagos State Government Electronic Banking - Revenue Collection and Monitoring (EBS-RCM). The mandate of Alpha-Beta Consulting Limited encompasses Revenue Statistical data collection and management, Accounting, and Strategic Monitoring as well as recommending the appointment of collecting banks for the DBLS. By the autonomous status granted to the new Lagos State Board of Internal Revenue and its operating arm as well as the professionalism being entrenched in the service, what will be the positions of Alpha-Beta Consulting Limited and Board of Internal revenue vis a vis the sole mandate of controlling and monitoring the revenue administration?

Section 10(6) of Lagos State Revenue Administration Law empowers the Board of Internal Revenue to employ the services of consultants including Tax Consultants or Accountants or Agents to carry out any act required in the execution of its functions. This is a novel distinction from the provisions of Personal Income Tax Law 1990 (Laws of Federal Republic of Nigeria) which abhors the appointment of consultants for the execution of the functions of the Board of Internal Revenue. A follow up from the challenge above, is the Alpha-Beta Consulting Limited and other Tax Audit Monitoring Agents now operate under exclusive control of the new Board of Internal Revenue?

- The Statistical data of Lagos State Government tax payers and the computerized monitoring system are currently with Alpha-Beta Consulting Limited. What will be the position if there is a sharp disagreement between the government and the firm necessitating immediate termination of the contract? The government revenue performance would be jeopardized.

- Alpha-Beta report of January 2006 indicated current Lagos State tax payers' data base of 375,000. The tax payers in the data base appear to be too few when compared with the State's estimated population of 16.2 million (at end of 2005) and considering average tax payers which is estimated at about $42 \%$ of this population which is 6.8 million. The current data base of taxpayers of 375,000 would represent a mere $6 \%$ of the estimated tax payers of Lagos State. The percentage of taxpayers in the tax net as a ratio of the potential tax payers is one of the basis of measuring effectiveness of revenue administration. 
- The efficiency of any revenue administration is measured on the basis of the revenue generated within a period as a ratio of the cost. Cost relates to the total costs expended to achieve the revenue figure. This is the cost of government's revenue collection machinery as a percentage of total revenue. The total commission paid to all Revenue Consultants (Alpha-Beta Consulting Limited, TAMA) is $10 \%$ of collection, this is in addition to the costs of running the autonomous Lagos Board of Internal Revenue which could increase the overall cost revenue ratio to about $15 \%$. Is the cost ratio of $15 \%$ reasonable?

\subsection{The problems of revenue generation}

The Lagos State government in Nigeria enjoyed an improved revenue from the 1970's till date due to reforms introduced by different regimes all aimed at making the state government effective and efficient in discharging statutory responsibilities to the people. This was achieved through increased sources of revenue generation; this problem is multifarious ranging from low borrowing capacity, corruption, mismanagement and misappropriation of state government funds, ineffective strategies for enhancing internally generally generated revenue, lack of skilled and technical personnel, etc.

\subsubsection{Mismanagement and misappropriation of state government funds}

This is one of the major problems of revenue generation in Lagos State; in most cases the state government funds have been mismanaged. Tax collectors that are charged with the responsibility to collect all the revenue sources do not adequately use their freedom to collect them and exploit other sources of revenue available to the state government. Many state government officials embezzle local government funds through all sorts of manner like inflating contracts or embarking on white elephant projects or outright siphoning of funds which has affected the developmental process of Lagos State.

\subsubsection{Corruption}

The internally generated revenue which was hoped to accelerate the finance of the state government is bedeviled by corrupt practices on the part of revenue collectors. It has been observed that these revenue collectors have in the possession unofficial receipts; this enables them to divert state government funds into private use. Corruption is the locust that has eaten state government revenue, this manifested in the distorting of revenue return receipts, embezzlement and misappropriation of funds.

\subsubsection{Poor financial management}

This arises from poor attitude to work as well as lack of integrity of revenue collectors.

4. Ineffective Strategies for Enhancing Internally Generated Revenue in the state government, was also contributed to poor revenue generation. These human related factors no doubt negatively affected development at the state government level which is the bedrock for genuine national development.

\subsection{Sources of state government revenue}

The sources of revenue of the state government can be divided into two parts viz: recurrent revenue and capital receipts.

a) The Recurrent Revenue:

i. Taxes: The taxes the states government collect are personal income tax; (excluding those of the Armed Forces, external affairs officers, foreign nationals, residents of the FCT, Abuja and the Nigerian Police Force) football pools and other betting taxes, capital gains tax, entertainment tax, stamp duties, capital transfer tax (CIT). 
ii. Licenses, Fees and Fines: These embrace motor vehicles and drivers' licenses. Land registration and survey fees and fines imposed on offenders.

iii. Earnings from economic activities: State governments do engage in some activities with a view to making profits. These include: establishments of banks, and investment ventures (For example; Oodua Investments) which involves sales of goods and services. Others are lotteries, rent on government properties and dividends.

iv. Allocation from the Federation Account: State governments are entitled to monthly allocation from the Federation Account which they share horizontally among themselves. It is, at present twenty-four percent of the total amount that accrues to the Federation Account.

v. Value-added Tax (VAT) allocation: It should be noted that VAT replaced sales tax which used to be exclusive preserve of the state governments. Therefore, at the inception of the VAT in 1994, the state government was given $80 \%$ of the proceeds from VAT. Even though the percentage has now been reduced to $50 \%$, but the state government will still receive the largest share of the VAT proceeds.

b) The Capital Receipts:

i. Grants: These usually come from the Federal Government. The purpose could be to enable a new state take off, or to carry out specific projects or to finance Federal Government programmes in the state. A good example is the projects under the Directorates of Food, Roads and Rural Infrastructures (DIFRRI).

ii. Loans: These can be internal or external loans. The internal loans represent borrowings by state governments from sources within the country. The sources include: individuals, organizations such as commercial banks, the Federal Government or other states. On the other hand, the external loans are ofteNn taken from the World Bank, International Monetary Fund (IMF), as well as foreign countries or organizations. However, approval must be received from the Federal Government before the loans can be obtained. Besides there is a limit to the amount of loan a state government can borrow or have outstanding at a time.

iii. Financial aids: These are funds from foreign countries or charitable international organizations such as UNICEF to execute in the states some humanitarian programmes like children immunization, control of epidemic diseases. The aids could also be meant to assist states that suffer some disasters. A good example is the case of Jesse fire disaster in Delta State towards the end of 1998 in which about one thousand persons were roasted to death. In the wake of the problem, the United States of America (USA) gave about N200m to the state to help assist the victims of the fire incident. The aids can also be in kind in form of relief materials or technical services.

\subsection{History of infrastructure}

According to the Online Etymology Dictionary, the word infrastructure has been used in English since at least 1927, originally meaning "The installations that form the basis for any operation or system".

Other sources, such as the Oxford English Dictionary, trace the word's origins to earlier usage, originally applied in a military sense. The word was imported from French, where it means subgrade, the native material underneath a constructed pavement or railway. The word is a combination of the Latin prefix "infra", meaning "below", and "structure". The military use of the term achieved currency in the United States after the formation of NATO in the 1940s, and was then adopted by urban planners in its modern civilian sense by 1970 . The term came to prominence in the United States in the 1980s following the publication of America in Ruins, which initiated a public-policy discussion of the nation's "infrastructure crisis", purported to be caused by decades of inadequate investment and poor maintenance of public works. This crisis discussion has contributed to the increase in infrastructure asset management and maintenance planning in the US.

The public-policy discussion was hampered by lack of a precise definition for infrastructure. A US National Research Council panel sought to clarify the situation by adopting the term "public works infrastructure", referring to: "... both specific functional modes - highways, streets, roads, and bridges; mass transit; airports and airways; water supply and water resources; wastewater management; solid-waste treatment and disposal; electric power generation and transmission; telecommunications; and hazardous waste management - and the combined system these modal elements comprise. A comprehension of infrastructure spans not only these 
public works facilities, but also the operating procedures, management practices, and development policies that interact together with societal demand and the physical world to facilitate the transport of people and goods, provision of water for drinking and a variety of other uses, safe disposal of society's waste products, provision of energy where it is needed, and transmission of information within and between communities."

In Keynesian economics, the word infrastructure was exclusively used to describe public assets that facilitate production, but not private assets of the same purpose. In post-Keynesian times, however, the word has grown in popularity. It has been applied with increasing generality to suggest the internal framework discernible in any technology system or business organization.

The term "infrastructure" could be defined in various aspects but, the researcher will define it as the provision of essential services and amenities to the industry and households in the society (Martini and Lee 1996). Hence, investment in infrastructure development projects is a key input in the development of the economy and a panacea to economic activity and growth. However, what is regarded as "essential", "key" and "panacea" changes from one country to another and from one period of time to another. For instance, the massive production of steel, coal and iron ore was once regarded as indispensable infrastructure.

\subsection{Types of infrastructure}

Infrastructures are of two types which are: "Hard" and "Soft" Infrastructure.

"Hard" infrastructure refers to the large physical networks necessary for the functioning of a modern industrial nation, whereas "soft" infrastructure refers to all the institutions which are required to maintain the economic, health, cultural and social standards of a country, such as the financial system, the education system, the health care system, the system of government, and law enforcement, as well as emergency services.

\section{Theoretical framework}

This study adopted the fiscal federation theory as the basis for this work. The basic foundations for the initial theory of Fiscal Federalism were laid by Kenneth Arrow, Richard Musgrave and Paul Sadweh Samuelson's two important papers $(1954,1955)$ on the theory of public goods, Arrow's discourse $(1970)$ on the roles of the public and private sectors and Musgrave's book (1959) on public finance provided the framework for what became accepted as the proper role of the state in the economy.

Within is framework, three roles were identified for the government sector. These were the roles of government in correcting various forms of market failure, ensuring an equitable distribution of income and seeking to maintain stability in the macro-economy at full employment and stable prices.

The theoretical framework in question was basically a Keynesian one which canvassed for an activist role of the state in economic affairs. Thus the government was expected to step in where the market mechanism failed due to various types of public goods characteristics. Economics teaches us that public goods will be underprovided if left to private market mechanisms since the private provider would under invest in their provision because the benefits accruable to her or him would be far lower than the total benefit to society. Governments and their officials were seen as the custodians of public interest who would seek to maximize social welfare based on their benevolence or the need to ensure electoral success in democracies.

Once we allow for a multi-level government setting, this role of the state in maximizing social welfare then provides the basic ingredients for the theory of fiscal federalism. Each tier of government is then seen as seeking to maximize the social welfare of the citizens within its jurisdiction. This multi-layered quest becomes very important where public goods exist, the consumption of which is not national in character, but localized. In such circumstances, local outputs targeted at local demands by respective local jurisdictions clearly provide higher social welfare than central provision. This principle, which Oats (1972) has formalized into the "Decentralization Theorem" constitutes the basic foundation for what may be referred to as the first generation theory of fiscal decentralization (Oats, 2004). The theory focused on situations where different levels of government provided efficient levels of outputs of public goods "for those goods whose special patterns of benefits were encompassed by the geographical scope of their jurisdictions" (Oats, 2004: 5). Such situation came to be known as "perfect mapping" or "fiscal equivalence" (Olson 1969). 
Nevertheless, it was also recognized that, given the multiplicity of local public goods with varying geographical patterns of consumption, there was hardly any level of government that could produce a perfect mapping for all public goods. Thus, it was recognized that there would be local public goods with inter-jurisdictional spill-overs. For example, a road may confer public goods characteristics, the benefits of which are enjoyed beyond the local jurisdiction. The local authority may then under-provide for such a good. To avoid this, the theory then resorts to traditional Pigouvian subsidies, requiring the central government to provide matching grants to the lower level government so that it can internalize the full benefits.

Based on the following, the role of government in maximizing social welfare through public goods provision came to be assigned to the lower tiers of government. The other two roles of income distribution and stabilization were, however, regarded as suitable for the central government. To understand the rationale for the assignment of the redistribution function to the central government, we need to examine what the implications of assigning this responsibility to the lower tier would imply. Given that citizens are freely mobile across local or regional jurisdictions, a lower level jurisdiction that embarks on a programme of redistribution from the rich to the poor would be faced with the out-migration of the rich to non-redistributing jurisdictions and in-migration of the poor from such jurisdictions to the redistributing one. If on the other hand, the powers to redistribute were vested in the central government, a redistribution policy would apply equally to citizens resident in all jurisdictions. There would therefore be no induced migration.

The central government is expected to ensure equitable distribution of income, maintain macroeconomic stability and provide public goods that are national in character. Decentralized levels of government on the other hand are expected to concentrate on the provision of local public goods with the central government providing targeted grants in cases where there are jurisdictional spill-overs associated with local public goods.

The next step in the theoretical framework was to determine the appropriate taxing framework. In addressing this tax assignment problem, attention was paid to the need to avoid distortions resulting from decentralized taxation of mobile tax bases. Gordon (1983) emphasized that the extensive application of nonbenefit taxes on mobile factors at decentralized levels of government could result in distortions in the location of economic activity.

The final element of this basic theory to note is the need for fiscal equalization. This is in the form of lump sum transfers from the central government to decentralized governments. The arguments for equalization were mainly two. The first which is on efficiency grounds saw equalization as a way of correcting for distorted migration patterns. The second is to provide assistance to poorer regions or jurisdictions. Equalization has been important in a number of federations. For example, Canada has an elaborate equalization scheme built into her inter-governmental fiscal arrangements.

It should be pointed out however, that recent literature emphasizes the importance of reliance on own revenues for financing local budgets. A number of authors (Weingast, 1995; McKinon, 1997) have drawn attention to the dangers of decentralized levels of government relying too heavily on intergovernmental transfers for financing their budgets.

\section{Methodology}

\subsection{Research design}

This is a non-experimental research setting based on survey design. It involves the gathering of information about the effect of internal revenue generation on the development of infrastructure. The study population used in this research comprised of workers in the internal revenue service in Lagos State. In order to have a sizable number for this study, the purposive sampling design was used as only people knowledgeable and experienced in the area under this study were selected. A total of fifty workers were selected for the study out of an estimated worker of about 100.

Data considered for the study were selected from primary and secondary sources. The primary source was basically questionnaire while the secondary source was from the books, journals and down load from the internet data base.

In order to obtain accurate and reliable information for this project, the researcher adopted two methods for data collection. These are questionnaire and statistical data. The questionnaire was divided into sections. 
Section A consists of the respondents' bio-data such as age, sex, qualifications, positions etc. In Section B, a tabular format was adopted for all the objectives of the study. It is structured in columns and rows and each column represents the observed response while the rows are the variables. The secondary means of data collection was through the statistical estimate of revenue within the period of seven years (2005-2011). This method was adopted in order to get the revenue of the Lagos State Government.

\subsection{Method of data analysis}

The data gathered for the study were subject to descriptive and inferential statistics. The descriptive statistics involves the use of simple percentage. The inferential statistics involves the use of Spearman's Rank which is to show the direction of relationship between variable under the study and to show the scale for the data which is interval.

Spearman's Rank Correlation:

$$
\mathrm{R}=\frac{1-6 \sum \mathrm{d}_{1}^{2}}{\underline{\mathrm{n}\left(\mathrm{n}^{2}-1\right)}}
$$

Where $d_{1}=$ difference in each pair of ranks $\mathrm{n}=$ number of objects being ranked

$R$ is defined in such a way that when the ranks are in perfect agreement, $R$ equals +1 and when they are in perfect disagreement $R$ equals -1 .

\section{Data presentation}

Demographic characteristics of respondents

Table 1 Gender of the respondents

\begin{tabular}{|c|c|c|c|c|}
\hline & & & & Cumulative \\
Gender & Frequency & Percentage & Valid Percentage & Percentage \\
\hline Male & 24 & 54.5 & 54.5 & 54.5 \\
Female & 20 & 45.5 & 45.5 & 100.0 \\
Total & 44 & 100.0 & 100.0 & \\
\hline
\end{tabular}

Source: Field Survey, 2012

The tables 1 above shows that 24 respondents are male and 20 respondents are female which represents $54.5 \%$ and $45.5 \%$ respectively. The result shows that majority of the Lagos state Internal Revenue Service workers are male.

Table 2: Age of the respondents

\begin{tabular}{|l|c|c|c|c|}
\hline & & & & Cumulative \\
Age & Frequency & Percentage & Valid Percentage & Percentage \\
\hline 21-30years & 16 & 36.4 & 36.4 & 36.4 \\
31-40years & 22 & 50.0 & 50.0 & 86.4 \\
41-50years & 5 & 11.4 & 11.4 & 97.7 \\
51-60years & 1 & 2.3 & 2.3 & 100.0 \\
Total & 44 & 100.0 & 100.0 & \\
\hline
\end{tabular}

Source: Field survey, 2012. 
The table 2 above shows that 16 respondents are between the age 21 and 30 which represents $36.4 \%, 22$ respondents are between the age of 31 and 40 which represents $50 \%, 5$ respondents are between the age of 41 and 50 which represents $11.4 \%$ and 1 respondent is between the age 51 and 60 which represents $2.3 \%$. The result shows that majority of the respondents were between the age of 31 and 40 years.

Table 3: Marital status of the respondents

\begin{tabular}{|c|c|l|l|l|}
\hline & & & & Cumulative \\
Marital Status & Frequency & Percentage & Valid Percentage & \begin{tabular}{l} 
Percentage \\
\hline Single
\end{tabular} \\
Married & 29 & 34.1 & 34.1 & 34.1 \\
Total & 44 & 65.9 & 65.9 & 100.0 \\
\hline
\end{tabular}

Source: Field survey, 2012

The table 3 above shows that 15 respondents are single which constitute $34.1 \%$ of the study while 29 respondents are married which constitutes $65.9 \%$ of the study. This result shows that more of married people amongst the respondents.

Table 4: Rank/ Position of the respondents

\begin{tabular}{|l|c|l|l|l|}
\hline & & & Valid & $\begin{array}{l}\text { Cumulative } \\
\text { Percentage }\end{array}$ \\
\hline Junk/ Position & Frequency & Percentage & Percentage & Peff \\
Middle management staff & 29 & 65.9 & 65.9 & 65.9 \\
Total & 15 & 34.1 & 34.1 & 100.0 \\
\hline
\end{tabular}

Source: Field survey, 2012

The table 4 above shows that 29 respondents are junior staffs which represents $65.9 \%$ while 15 respondents are middle management staffs which represents $34.1 \%$ of the study. The result shows that more of the workers are junior staffs.

Table 5: Education qualification of the respondents

\begin{tabular}{|c|l|l|l|l|}
\hline Education Qualification & & & $\begin{array}{l}\text { Valid } \\
\text { Percentage }\end{array}$ & $\begin{array}{l}\text { Cumulative } \\
\text { Percentage }\end{array}$ \\
\hline HND/DEGREE & Frequency & Percentage & 84.1 & 84.1 \\
MASTERS/PHD & 37 & 9.1 & 9.1 & 84.1 \\
PROFESSIONALS & 4 & 6.8 & 6.8 & 93.2 \\
Total & 3 & 100.0 & 100.0 & 100.0 \\
\hline
\end{tabular}

Source: Field survey, 2012

The table 5 shows that 37 respondents have HND/DEGREE which represents $84.1 \%, 4$ respondents have MASTERS/PHD which represents $9.1 \%$ and 3 respondents have PROFESSIONALS which represents $6.8 \%$. The result shows that more of the respondents are HND/DEGREE holders. 
Table 6: Cognate Working Experience

\begin{tabular}{|c|c|c|c|c|}
\hline Working Experience & Frequency & Percentage & $\begin{array}{l}\text { Valid } \\
\text { Percentage }\end{array}$ & $\begin{array}{l}\text { Cumulative } \\
\text { Percentage }\end{array}$ \\
\hline 1year- 5years & 13 & 29.5 & 29.5 & 29.5 \\
\hline 6years-10years & 20 & 45.5 & 45.5 & 75.0 \\
\hline 11 years-15years & 9 & 20.5 & 20.5 & 95.5 \\
\hline 16years-20years & 1 & 2.3 & 2.3 & 97.7 \\
\hline Above 20years & 1 & 2.3 & 2.3 & 100.0 \\
\hline Total & 44 & 100.0 & 100.0 & \\
\hline
\end{tabular}

Source: Field survey, 2012.

The table 6 above shows that 13 respondents have between $1-5$ years working experience which represents $29.5 \%, 20$ respondents have between 6 - 10 years working experience which represents $45.5 \%$, 9 respondents have between $11-15$ years working experience which represents $20.5 \%$, 1 respondent have between $16-20$ years working experience which represents $2.3 \%$ and 1 respondent have above 20 years of working experience. The experiences gathered will enable the respondents be a better judge for this study.

\section{Data analysis}

Table 7: Lagos state government is doing enough to create awareness about the importance of paying taxes

\begin{tabular}{|c|l|l|l|l|}
\hline & & & & \\
Description & Frequency & Percentage & Valid Percentage & Cumulative Percentage \\
\hline A & 10 & 22.7 & 22.7 & 22.7 \\
SA & 34 & 77.3 & 77.3 & 100.0 \\
Total & 44 & 100.0 & 100.0 & \\
\hline
\end{tabular}

Source: Field survey, 2012.

The table 7 above shows that 44 respondents agreed which represents $100.0 \%$. With the above response, one can conclude that Lagos state government is doing enough to create awareness about the importance of paying taxes.

Table 8: The level of infrastructural development has encouraged more people to pay their taxes.

\begin{tabular}{|c|l|l|l|l|}
\hline & & & & Cumulative \\
Description & Frequency & Percentage & Valid Percentage & \begin{tabular}{l} 
Percentage \\
\hline U
\end{tabular} \\
D & 1 & 2.3 & 2.3 & 2.3 \\
A & 37 & 2.3 & 2.3 & 4.5 \\
SA & 5 & 84.1 & 84.1 & 88.6 \\
Total & 44 & 11.4 & 11.4 & 100.0 \\
\hline
\end{tabular}

Source: Field survey, 2012. 
The table 8 above shows that 1 respondent was undecided which represents $2.3 \%$, 1 respondent disagreed which represents $2.3 \%$ and 42 respondents agreed which represents $95.5 \%$. This response implies that the level of infrastructural development has encouraged more people to pay their taxes.

Table 9: Tax enforcement laws in Lagos state are adequate.

\begin{tabular}{|c|l|l|l|l|}
\hline & & & & Cumulative \\
Description & Frequency & Percentage & Valid Percentage & \begin{tabular}{l} 
Percentage \\
\hline D
\end{tabular} \\
A & 45 & 9.1 & 9.1 & 9.1 \\
SA & 5 & 79.5 & 79.5 & 88.6 \\
Total & 44 & 11.4 & 11.4 & 100.0 \\
\hline
\end{tabular}

Source: Field survey, 2012.

The table 9 above shows that 4 respondents disagreed which represents $9.1 \%$ and 40 respondents agreed which represents $90.9 \%$. This implies that tax enforcement laws in Lagos state are adequate.

Table 10: There would be more infrastructural development in Lagos state if people pay their taxes adequately

\begin{tabular}{|c|l|l|l|l|}
\hline & & & Valid & Cumulative \\
Description & Frequency & Percentage & Percentage & \begin{tabular}{l} 
Percentage \\
\hline U
\end{tabular} \\
SD & 1 & 2.3 & 2.3 & 2.3 \\
D & 1 & 2.3 & 2.3 & 4.5 \\
A & 33 & 2.3 & 2.3 & 6.8 \\
SA & 8 & 75.0 & 75.0 & 81.8 \\
Total & 44 & 18.2 & 18.2 & 100.0 \\
\hline
\end{tabular}

Source: Field survey, 2012.

The table 10 above shows that 1 respondent was undecided which represents $2.3 \%$, 2 respondents disagreed which represents $4.6 \%$ and 41 respondents agreed which represents $93.2 \%$. This response implies that there would be more infrastructural development in Lagos state if people pay taxes adequately.

Table 11: The effect of revenue generation is rated on the development of infrastructures.

\begin{tabular}{|c|l|l|l|l|}
\hline & & & & Cumulative \\
Description & Frequency & Percentage & Valid Percentage & \begin{tabular}{l} 
Percentage \\
\hline D
\end{tabular} \\
\hline A & 29 & 4.5 & 4.5 & 4.5 \\
SA & 13 & 65.9 & 65.9 & 70.5 \\
Total & 44 & 29.5 & 29.5 & 100.0 \\
\hline
\end{tabular}

Source: Field survey, 2012.

The table 11 above shows that 2 respondents disagreed which represents $4.5 \%$ and 42 respondents agreed which represents $95.4 \%$. This implies that the effect of revenue generation is rated on the development of infrastructures. 
Table: 12 Poor infrastructures have led to loss of lives

\begin{tabular}{|c|l|l|l|l|}
\hline & & & Valid & $\begin{array}{l}\text { Cumulative } \\
\text { Percentage }\end{array}$ \\
\hline Description & Frequency & Percentage & Percentage & Percis \\
SD & 1 & 2.3 & 2.3 & 2.3 \\
D & 1 & 2.3 & 2.3 & 4.5 \\
A & 2 & 4.5 & 4.5 & 9.1 \\
SA & 20 & 45.5 & 45.5 & 54.5 \\
Total & 20 & 45.5 & 45.5 & 100.0 \\
\hline
\end{tabular}

Source: Field Survey, 2012.

The table 12 above shows that 1 respondent was undecided which represents $2.3 \%, 3$ respondents disagreed which represents $6.8 \%$ and 40 respondents agreed which represents $93.3 \%$. This response implies that poor infrastructures have led to loss of lives.

Table 13: Workers in Lagos state contribute to revenue generation

\begin{tabular}{|c|l|l|l|l|}
\hline & & & & Cumulative \\
Description & Frequency & Percentage & Valid Percentage & Percentage \\
\hline A & 16 & 36.4 & 36.4 & 36.4 \\
SA & 28 & 63.6 & 63.6 & 100.0 \\
Total & 44 & 100.0 & 100.0 & \\
\hline
\end{tabular}

Source: Field survey, 2012.

The table 13 above shows that 44 respondents agreed which represents $100.0 \%$. This response implies that workers in Lagos state contribute to revenue generation.

Table 14: Lagos State is ahead of other states in the provision of basic infrastructures

\begin{tabular}{|c|l|l|l|l|}
\hline & & & & Cumulative \\
Description & Frequency & Percentage & Valid Percentage & \begin{tabular}{l} 
Percentage \\
\hline U
\end{tabular} \\
D & 1 & 2.3 & 2.3 & 2.3 \\
A & 1 & 2.3 & 2.3 & 4.5 \\
SA & 10 & 22.7 & 22.7 & 27.3 \\
Total & 32 & 72.7 & 72.7 & 100.0 \\
\hline
\end{tabular}

Source: Field survey, 2012.

The table 14 above shows that 1 respondent was undecided which represents $2.3 \%, 1$ respondent disagreed which represents $2.3 \%$ and 42 respondents agreed which represents $95.4 \%$. This response implies that Lagos state is ahead of other states in the provision of basic infrastructure. 
Table 15: The infrastructural development of Lagos state is as a result of adequate revenue generation

\begin{tabular}{|c|l|l|l|l|}
\hline & & & & Cumulative \\
Description & Frequency & Percentage & Valid Percentage & \begin{tabular}{l} 
Percentage \\
\hline D
\end{tabular} \\
\hline A & 34 & 4.5 & 4.5 & 4.5 \\
SA & 8 & 77.3 & 77.3 & 81.8 \\
Total & 44 & 18.2 & 18.2 & 100.0 \\
\hline
\end{tabular}

Source: Field survey, 2012.

The table 15 above shows that 2 respondents disagreed which represents $4.5 \%$ and 42 respondents agreed which represents $95.5 \%$. This implies that the infrastructural development of Lagos state is as a result of adequate revenue generation.

Table 16: Revenue generation agencies in Lagos state are efficient

\begin{tabular}{|c|l|l|l|l|}
\hline & & & & Valid Percentage \\
Description & Frequency & Percentage & $\begin{array}{l}\text { Cumulative } \\
\text { Percentage }\end{array}$ \\
\hline SD & 1 & 2.3 & 2.3 & 2.3 \\
A & 38 & 86.4 & 86.4 & 88.6 \\
SA & 5 & 11.4 & 11.4 & 100.0 \\
Total & 44 & 100.0 & 100.0 & \\
\hline
\end{tabular}

Source: Field survey, 2012.

The table 16 above shows that 1 respondent disagreed which represents $2.3 \%$ and 43 respondents agreed which represents 97.8\%. This response implies that revenue generation agencies in Lagos state are efficient.

Table 17: Revenue generation supports infrastructural development

\begin{tabular}{|c|c|c|c|c|}
\hline Description & Frequency & Percentage & Valid Percentage & $\begin{array}{l}\text { Cumulative } \\
\text { Percentage }\end{array}$ \\
\hline A & 34 & 77.3 & 77.3 & 77.3 \\
\hline SA & 10 & 22.7 & 22.7 & 100.0 \\
\hline Total & 44 & 100.0 & 100.0 & \\
\hline
\end{tabular}

Source: Field survey, 2012.

The table 17 above shows that 44 respondents agreed which represents $100.0 \%$. This implies that revenue generation supports infrastructural development. 
Table 18: The training of tax personnel is the only effective and lasting solution to the problem of revenue generation

\begin{tabular}{|c|l|l|l|l|}
\hline & & & $\begin{array}{l}\text { Valid } \\
\text { Percentage }\end{array}$ & $\begin{array}{l}\text { Cumulative } \\
\text { Percentage }\end{array}$ \\
\hline Description & Frequency & Percentage & 4.5 & 4.5 \\
D & 2 & 4.5 & 50.0 & 54.5 \\
SA & 22 & 50.0 & 45.5 & 100.0 \\
Total & 20 & 45.5 & 100.0 & \\
\hline
\end{tabular}

Source: Field survey, 2012.

The table 18 above shows that 2 respondents disagreed which represents $4.5 \%$ and 42 respondents agreed which represents $95.5 \%$. This response implies that the training of tax personnel is the only effective and lasting solution to the problem of revenue generation.

\section{Test of hypothesis}

$\mathrm{H}_{0}$ : Effective internal revenue generation leads to the development of infrastructure.

$\mathrm{H}_{1}$ : Effective internal revenue generation does not lead to the development of infrastructure.

Nonparametric Correlation

Table 19 Correlations

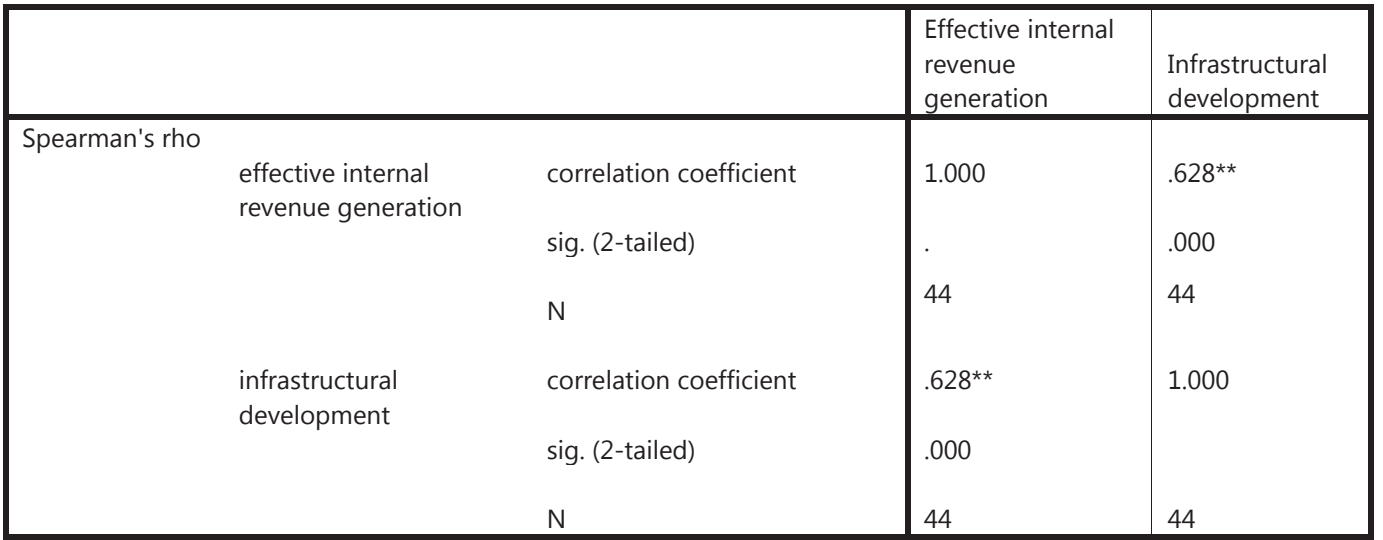

${ }^{* *}$ Correlation is significant at the 0.01 level (2-tailed).

Interpretation: rho $=0.628, \mathrm{~N}=44$ and $\mathrm{P}<0.005$ as shown on the table 4.4.1 above, we can conclude that there is a positive relationship between hypothesis and accept the alternative hypothesis and conclude that effective internal revenue generation leads to the development of infrastructure.

$\mathrm{H}_{0}$ : There is internal control measures put in place to ensure effective utilization of revenue generated.

$\mathrm{H}_{1}$ : There is no internal control measures put in place to ensure effective utilization of revenue generated.

Nonparametric Correlations 
Table 20 Correlations

\begin{tabular}{|c|c|c|c|c|}
\hline & & & $\begin{array}{l}\text { Internal } \\
\text { Control } \\
\text { measures }\end{array}$ & $\begin{array}{l}\text { Effective } \\
\text { utilization of } \\
\text { revenue } \\
\text { generated }\end{array}$ \\
\hline \multirow[t]{5}{*}{ Spearman's rho } & internal Control measures & $\begin{array}{l}\text { correlation coefficient } \\
\text { sig. (2-tailed) }\end{array}$ & 1.000 & $\begin{array}{l}.717^{\star *} \\
.000\end{array}$ \\
\hline & & $\mathrm{N}$ & 44 & 44 \\
\hline & $\begin{array}{l}\text { effective utilization of } \\
\text { revenue generated }\end{array}$ & correlation coefficient & & 1.000 \\
\hline & & sig. (2-tailed) & .000 & \\
\hline & & $\mathrm{N}$ & 44 & 44 \\
\hline
\end{tabular}

** Correlation is significant at the 0.01 level (2-tailed).

Interpretation: rho $=0.717, \mathrm{~N}=44$ and $\mathrm{P}<0.005$ as shown on the table above, we can conclude that there is a positive relationship between Internal Control measures and effective utilization of revenue generated .Therefore we reject the null hypothesis and accept the alternative hypothesis and conclude that there is internal control measures put in place to ensure effective utilization of revenue generated.

$\mathrm{H}_{0}$ : There are laid down procedures for revenue collection.

$\mathrm{H}_{1}$ : There are no laid down procedures for revenue collection.

Nonparametric Correlations

Table 21 Correlations

\begin{tabular}{|c|c|c|c|c|}
\hline & & & $\begin{array}{l}\text { Laid down } \\
\text { procedures }\end{array}$ & $\begin{array}{l}\text { Revenue } \\
\text { collection }\end{array}$ \\
\hline \multirow[t]{5}{*}{ Spearman's rho } & laid down procedures. & $\begin{array}{l}\text { correlation coefficient } \\
\text { sig. }(2 \text {-tailed) }\end{array}$ & 1.000 & $\begin{array}{l}.837^{* \star} \\
.000\end{array}$ \\
\hline & & $\mathrm{N}$ & 44 & 44 \\
\hline & revenue collection & correlation coefficient & $.837^{\star \star}$ & 1.000 \\
\hline & & sig. (2-tailed) & .000 & \\
\hline & & $\mathrm{N}$ & 44 & 44 \\
\hline
\end{tabular}

** Correlation is significant at the 0.01 level (2-tailed).

Interpretation: rho $=0.837, \mathrm{~N}=44$ and $\mathrm{P}<0.005$ as shown on the table 4.4 .3 above, we can conclude that there is a positive relationship between laid down procedures and revenue collection .Therefore we reject the null hypothesis and accept the alternative hypothesis and conclude that there are there are laid down procedures for revenue collection.

\section{Summary of findings}

The statistical analysis used in this study revealed that the effect of internal revenue generation has led to infrastructural development. 
It was observed that the workers in Lagos state contribute to revenue generation. The researcher also discovered that the infrastructural development in Lagos state is as a result of adequate generated revenue and that revenue generation supports infrastructural development.

Furthermore, it was observed that Lagos state is ahead of other states in the provision of basic infrastructures. It has also been observed that revenue agencies in Lagos state are efficient.

Finally, the researcher's findings was that the major method to be adopted by the Lagos state government in order to improve revenue generation base should be the enlightenment of the citizens on the need and important of regular payment of taxes.

\section{Conclusion}

Given the very low starting level of Internally Generated Revenue in 1999, the continuous improvement in revenue collection since the return to democratic governance is not a sufficient proof of the efficiency of the revenue administration arrangements recently put in place. There is a revenue administration cost issue that needs attention to ensure that the burden of revenue administration on the State remains reasonable.

This research work posits that the generation of revenue contributes significantly to the development of infrastructures. This study has endeavored to exhaust the administration, strategies, challenges and problem of revenue in Lagos state and the history, types and uses of infrastructure. The reasons and methods were also analyzed and solutions to these problems were dealt with.

In order to get the best out of revenue system, a lot has to be done in Lagos state by creating awareness about the importance of paying taxes.

\section{Recommendations}

Based on this research work, the researcher made the following recommendations:

Establishment of projects: The state government should embark on the establishment of some mini-size industries which will provide employment opportunities to the people. There should also be development and improvement in agricultural ventures like crop farming etc. the participation in agriculture will encourage the inhabitants of this local government area to improve their standard of living.

Supply of social and economic services: Efforts of state government should not only be directed towards the revenue yielding alone but also to the provision of social services like good wards, basic health facilities, environmental sanitation, town halls, street light, water supply. These facilities should be of high quality, by doing this; the people's interest will be geared towards giving their maximum support to the governments at all facts where such cooperation is required. Once, some of their interest are taken care of, the people will feel committed to paying to the local government all revenue due from them and this will improve the revenue strength of the local government in question.

Staff motivation: Workers should be encouraged so that they can put in their maximum services and when this is done, there will be increase or solid improvement in revenue collection. Training of workers for knowledge enhancement should be one of such motivational factors. It is fervently hoped that when the above suggestions are fully implemented, the local government will not only improve internally but also with the outside world.

This research work also recommended that the sources of revenue that are significant such as taxes, licenses, fines and fees, grants, financial aids and loans should be reconstructed and re-engineered through public awareness, keeping of accurate data and methodical manner of collection. Lagos state government has great potential to become one of the most efficient and highest generated revenue government if efforts are made to improve collection and generation performance.

\section{References}

Adekanola, O., (1996). Legality of the appointment of consultants for revenue generation. Paper delivered at a seminar organized by the CITN.

Arthur, J.A., (2010). Practical research methodology design analysis and reporting. (5 ${ }^{\text {th }}$ ed). Lagos: Jovilla Publishers.

Fatoyinbo, I., (2006). Introductory statistics for tertiary institutions. Ilaro: Delak Ventures: 10- 13. 
Infrastructure, Online Compact Oxford English Dictionary (2009). Infrastructure. Retrieved on the $7^{\text {th }}$ of May, 2012 from http://www.askoxford.com/concise_oed/infrastructure.

Ojo, S. A. (2000). Principles of Nigerian tax. Ilorin: Sagribra Publishing House; 70

Okoh, R.N., (2004). Revenue sharing in Nigeria: A retrospective evaluation. In Garba, A.G., Equraikhide. F. \& A. Adenikinju (eds.). Leading issues in macroeconomic management and development, Ibadan, : Nigeria Economics Society.

Ola, C.S., (1988). Boosting Revenue Generation by State Governments in Nigeria. Strategies for enhanced tax revenue in Nigeria, 8(4).

Olowononi, G.D., (2000). An evaluation of revenue allocation formula in Nigeria.CBN

Olusola, O. O. (2011). Boosting internally generated revenue of local government. European Journal of Humanities and Social Sciences, 8(1).

Soyode, L. \& Kajola, S. O. (2006). Taxation principles and practice in Nigeria. ( $1^{\text {st }}$ edu). Ibadan: Silon Publishing Company, 6-12, 62.

Zeeuw, M. A. \& Abdulrazaq, T., (2005). Tax policy assessment for Lagos state government. Retrived on the $12^{\text {th }}$ of May, 2012 from www.slgpnigeria.org/uploads/File/318.pdf. 